УДК 17.31 .01

DOI:

Ольга Сов'як, магістр кафедри початкової та дошкільної освіти Львівського національного університету імені Івана Франка

\title{
СТИЛЬ ВЗАЄМИН МІЖ БАТЬКАМИ ЯК ЧИННИК МОРАЛЬНОГО ВИХОВАННЯ ДОШКІЛЬНИКІВ
}

Стаття присвячена аналізу взаємозв 'язку стилю взаємин батьківських стосунків з моральним розвитком дітей дошкільного віку. Визначено, що моральна поведінка виникає під час пошуку дитиною різноманітних варіантів вирішення ситуації, вибіркового ставлення дошкільника до інших та самого себе. Моральний розвиток дитини дошкільника здійснюється на основі освоєння нею моральних знань $і$ морального досвіду 6 родині, емочійного переживання моральних стосунків у сім'ї.

Ключові слова: дитина дошкільного віку; стиль сімейних взаємин; моральне виховання; моральний розвиток.

Jim. 4.

Olha Sovyak, Master Student of the Primary and Preschool Education Department Lviv Ivan Franko National University

\section{THE STYLE OF RELATIONSHIPS BETWEEN PARENTS AS A FACTOR IN THE MORAL UPBRINGING OF PRESCHOOLERS}

The article is devoted to the analysis of the relationship between parental and child relationships and the style of education with the moral development of children of preschool age. It is noted that the leading role in the moral development of preschool children belongs to the family. It is noted that unselfish communication from close adults causes children a sense of security, emotional well-being. All this affects the early awareness of ethical norms of behavior, the development of adequate emotional reactions, susceptibility to moral attitudes and moral behavior of children.

It has been determined that for the formation of the moral formation of the person an important role belongs to the stimulating and developing environment, which parents create for the child, laying in its nature the program of good.

The author stresses that approach to children without excessive concentration of attention, without excessive emotional distance, which can be characterized as balanced, free, is a prerequisite for the moral development of the child. The superficiality of the parents' interest in the life of the child leads to the child's ignorance of moral norms and the undeveloped moral feelings, while in expanding the sphere of parental feelings in parents, fear arises from the independence of the child, so that this state creates obstacles to the development of activity and interest of the child in the activity. Favorable support for the development of the moral sphere of the child will be an approach (style) based on the recognition of the parents of the position of the child's internal independence, which manifests itself in moderate categorical and persistence, respect for the child's individuality.

Keywords: a child of preschool age; a style of family relationships; moral education; moral development.

П остановка проблеми. Серед проблем сучасної вітчизняної системи виховання та освіти все активніше обговорюються питання моральної освіченості підростаючого покоління. Адже дитина не народжується моральною чи аморальною, а поступово стає такою в залежності, в якому середовищі, в яких умовах виховується. Україна переживає один із непростих історичних періодів. Найбільша небезпека полягає не лише в руйнуванні економіки чи змінах політичної системи, а й у руйнуванні моральних засад особистості.

У зв'язку з цим відводиться особлива роль сім'ї, яка забезпечує успішне функціонування дитини як суб’єкта власної життєдіяльності, що визначає сім'ю незамінною формою відтворення суспільного життя дошкільника, чинника морального виховання.

Значення дошкільного періоду у розвитку дитини не можливо переоцінити. Дошкільне дитинство - короткий, але важливий період ствердження особистості. В ці роки у дитини починає формуватися певне відношення до людей, до праці, виробляються навички і звички правильної поведінки, зароджується характер, засвоюються суспільні цінності й норми, закладаються основи світогляду і загальної культури, моральні норми та цінності.

Мета статті - обгрунтувати проблему впливу стилю взаємин між батьками на моральне виховання дітей дошкільного віку. 
Аналіз останніх досліджень і публікацій. Вагомий внесок у розробку проблем сімейного виховання зробили видатні вітчизняні вчені К. Ушинський, С. Русова,А.Макаренко,В.Сухомлинський, М. Стельмахович та інші. Саме К. Ушинський, В. Сухомлинський, М. Стельмахович дали обгрунтування сім'ї як важливого первинного природного осередку, де виховуються діти.

Вивченням та класифікацією типів, стилів батьківського ставлення до дитини займалися вчені: І. Бех, А. Богуш, Н. Василенко, Л. Коваль, І. Кон, Р. Овчарова, С. Рубінштейн, О. Сухомлинська, Д. Фельдштейн. В останні роки викликає зацікавленість науковців проблема морального виховання дітей дошкільноговіку,таких як І. РогальськаЯблонська, Н. Гнатуш, Т. Поніманська, О. Кононко та ін.

Виклад основного матеріалу. Моральний розвиток особистості розглядається як "процес засвоєння визначених у суспільстві еталонів поведінки, у результаті цього вони стають регуляторами поведінки особистості” [1, 403].

Відповідно, дитина з малку вчиться діяти за приписами моралі, дотримуватись моральних норм як основи людських стосунків. Так, В. Сухомлинський говорив про те, що “необхідно займатися моральним вихованням дитини, навчати - уміння відчувати людину” [4, 160].

Про моральність можна говорити тільки тоді, коли “особистість морально поводиться в силу внутрішнього спонукання, коли її власні погляди і переконання виконують функцію самоконтролю. Вироблення таких поглядів, переконань i відповідних їм звичок поведінки і становлять сутність морального виховання".

Серед педагогів не існує загальноприйнятої точки зору щодо структури моральної поведінки особистості. Розглядаючи різні підходи вчених до визначення структури моральної поведінки особистості, можна виділити загальні структурні компоненти, що характерні для кожного із підходів.

Так, Л. Василенко вважає, що “моральна поведінка особистості структурно характеризується наявністю: ієрархії моральних цінностей; моральних уявлень; моральних поглядів; моральних переконань; моральних мотивів, що реалізуються у вчинках й поведінці; раціональні та емоційні елементи” $[2,77]$.

Досліджуючи проблему виховання моральної поведінки О. Кононко, [3, 267] виділяє такі їі структурні елементи - “моральні уявлення; моральні поняття; моральні знання; моральні переконання; ціннісні орієнтації; інтерес до моральних проблем; моральні мотиви; моральні стосунки”.
Моральний розвиток дитини дошкільника здійснюється на основі освоєння нею моральних знань і морального досвіду, емоційного переживання моральних стосунків. Від того, як вони будуть сформовані у перші роки життя дитини, багато в чомузалежить увесь ії наступний розвиток.

“Рушійними силами розвитку психіки дошкільника $\epsilon$ суперечності, які виникають у зв'язку з виникненням нових потреб дитини, найважливіші з яких: потреба у спілкуванні, завдяки якій засвоюється соціальний досвід; потреба у зовнішніх враженнях, у результаті цього відбувається розвиток пізнавальних здібностей; потреба у руховій активності, що призводить до оволодіння цілою системою різноманітних практичних навичок та вмінь" - зазначає у своєму дослідження Л. Василенко [2, 78]. Розвиток провідних соціальних потреб у дошкільному віці характеризується тим, що кожна 3 них набуває самостійного значення.

У дошкільному віці відбувається формування рівня буденної моральності на основі включення дитини у систему соціальної взаємодії. Засвоєння знань про моральні норми і вимоги, перетворення їх на відповідні мотиви поведінки, передбачає усвідомлення дошкільником системи моральних цінностей. Цінності і ціннісні орієнтації виступають базовими елементами моральної сфери особистості дошкільника, пов’ язуючи в єдине ціле адекватні і буденні моральні уявлення у свідомості дитини.

Одночасно, слід зазначити, що дітям особливо важко вибрати між особисто значущими і суспільно важливими мотивами. Для того, щоб знання дитиною моральних норм не розходилося з їх реалізацією у поведінці, зазначає О. Кононко, “необхідною умовою $є$ перетворення норми на внутрішню спонуку, мотив соціальної поведінки або раціональне прийняття дитиною моральної форми як необхідної, доцільної, корисної. Зовнішня соціальна норма має пов'язуватись в свідомості дошкільника 3 його моральними потребами, інтересами, переконаннями, мотивами, ідеалами, самооцінкою. Норма має перетворитись на внутрішню вимогу дитини до самої себе, реалізовуватись без контролю і тиску ззовні” [3, 280]. Першим етапом засвоєння моральних форм поведінки є виникнення уявлень про них.

Сучасні наукові дослідження розвитку духовно-моральної сфери особистості виявили, що процес іiї формування має соціальну зумовленість, а тому залежить від правил та установок, прийнятих у даному суспільстві. В той же час духовно-моральне виховання залежить від 
моральних установок, норм, традицій виховання у конкретній сім'ї, родині, дошкільній установі. Необхідно відзначити, що у сучасних сім'ях відбулися значні зрушення.

Педагоги та психологи відзначають, що соціоцентрична модель сімейних стосунків змінилася на так звані людиноцентричну та дітоцентричну моделі $[2,77]$. В той же час у частини сучасних батьків спостерігається повна неуважність до проблем духовно-морального та соціально-морального розвитку дитини. Це можна пояснити їхньою надзайнятістю, забезпеченням насамперед матеріальних благ для сім'ї. Але, “за відсутності цілеспрямованого морального виховання, коли навколишні піклуються лише про задоволення фізичних потреб маленької дитини, не привчаючи іiї з перших років життя до виконання найпростіших обов'язків перед оточуючими, до дотримання найпростіших моральних норм, невідворотно виникає дитячий егоїзм, неодноразово описаний у літературі з дитячої психології, що загрожує у подальшому перетворитись у значно менше наївний і набагато небезпечніший егоїзм вже дорослого. Але егоїзм дитини не є обов'язковою особливістю віку, а є значною мірою недоліком виховання, наслідком бідності та обмеженості соціально-морального досвіду дитини, зокрема уявлень про моральні норми" $[2,77]$.

Дошкільне дитинство - період, коли почуття та емоції домінують над усіма іншими аспектами життя дитини, в неї складається початкове розуміння моральних норм, формуються моральні оцінки та критерії, засвоюються моральні знання, але ще немає прямої відповідності між знанням моральних норм та їх виконанням, а тільки виникають паростки довільної позитивно спрямованої поведінки [3, 276].

Науковці переконані, що виховний вплив сім’ї на дітей в різні періоди їхного дитинства не $\epsilon$ рівнозначним. Особливо значущий для становлення особистості вплив батьків у період дошкільного дитинства. Діти дошкільного віку найбільш сприятливі до цілеспрямованого та стихійного впливу - як позитивного, так і негативного. У них ще відсутній власний соціальний досвід, тому їхнє сприйняття впливів соціального середовища (яке у цей час уособлює сім'я) найтриваліше і найміцніше.

Моральний розвиток дитини-дошкільника складний і суперечливий процес, і провідна роль у ньому належить родині. Лише у спілкуванні 3 люблячими батьками діти отримують уявлення про моральні правила та норми, позитивні або негативні емоційні реакції на свої вчинки.

Турботливе спілкування 3 боку близьких дорослих викликає в дітей відчуття захищеності, емоційного благополуччя. Все це впливає на раннє усвідомлення етичних норм поведінки, розвиток адекватних емоційних реакцій, сприйнятливість до моральних установок і моральну поведінку дітей.

Висновок. Отже, сім'я має вирішальне значення уформуванні емоційного та соціального самопочугтя дитини, іiї самоусвідомлення і моральних основ особистості. Саме в сім’ї дитина у період дошкільного дитинства отримує життєво важливі уявлення, набуває необхідних для життя соціальних умінь і навичок. Незважаючи на всю ту кризу, яку сьогодні переживає сім'я, вона залишається одним iз найголовніших інститугів соціалізації особистості, яку в більшості випадків здійснює стихійно.

\section{ЛІТЕРАТУРА}

1. Бех І. Д. Виховання особистості: навчальнометодичний посібник. - К.: Либідь, 2003. - 848 с.

2. Василенко Л.П. Психологічні умови засвоєння моральних норм дітьми дошкільного віку / Л.П. Василенко // Моральна свідомість та самосвідомість особистості: монографія / за ред. проф. М.В. Савчина, доц. I.М. Галяна. Дрогобич, 2009. - С. 76 - 93.

3. Кононко О.Л. Психологічні основи особистісного становлення дошкільника (Системний підхід) / О.Л. Кононко. - К.: Стилос, 2002. - 336 с.

4. Сухомлинский В. А. Сердце отдаю детям / Сухомлинский В. А. - 8-е изд. - К.: Рад. школа, 1984. -288 c.

\section{REFERENCES}

1. Bekh, I. D. (2003). Vykhovannia osobystosti: navchalno-metodychnyi posibnyk [The education of the person: an educational and methodological manual]. Kyiv: Lybid, 848 p. [in Ukrainian].

2. Vasylenko, L. P. (2009). Psykholohichni umovy zasvoiennia moralnykh norm ditmy doshkilnoho viku [The psychological conditions of assimilation of moral norms by preschool children]. Moralna svidomist ta samosvidomist osobystosti: monohrafiia [Moral consciousness and selfconsciousness of the individual: a monograph]. (Ed.). M. V. Savchyn, I. M. Halian. Drohobych, pp. 76-93. [in Ukrainian].

3. Kononko, O. L. (2002). Psykholohichni osnovy osobystisnoho stanovlennia doshkilnyka (Systemnyi pidkhid) [Psychological foundations of the personal formation of a preschooler (System approach)]. Kyiv: Stylos, 336 p. [in Ukrainian].

4. Sukhomlinskiy, V. A. (1984). Serdtse otdayu detyam [I give my heart to the children]. The 8th ed. Kyiv: Rad. shkola, 288 p. [in Russian].

Стаття надійшла до редакції 28.08.2018 